\title{
CALGARY AND EVERYTHING AFTER: A POSTMODERN RE-VISION OF LAWYERING
}

\section{ALLAN C. HUTCHINSON}

Hutchinson encourages a re-thinking of the ethics of lawyering. He explores the need to transform through legal theory what is done in legal practice and what is justified to be left undone. This exploration begins with a discussion of the traditional image of the ethical lanyer. He then exposes this image to a series of critiques and introduces alternate models of legal practice. A postmodern vision of lawyering is introduced which reframes and reworks these traditional ways of thinking. By the adoption of such a postmodern revision of lawyering, change in legal practice may come about through the legal profession, rather than in spite of it.

\begin{abstract}
Hutchinson propose de repenser l'éthique du barreau. Il explore la nécessité de transformer par le biais de la théorie du droit ce qui se fait dans la pratique du droit et ce dont il convient de s'abstenir. Cette exploration commence par une discussion portant sur l'image traditionnelle de l'avocat respectueux de l'éthique. La discussion se poursuit dans le contexte des critiques de ce modèle et d'autres modèles possibles. Il propose une vision postmoderne du barreau qui transcende ces modes de pensée conventionnels. Cette vision postmoderne révisée permettra peut-être que la pratique juridique évolue grâce à la profession et non pas en dépit d'elle.
\end{abstract}

\section{INTRODUCTION}

Much to my teenaged daughters' chagrin, I listen to and enjoy some of the same music as they do - "But if you like it, it can't be much good." One of the best new bands around is Counting Crows. Inspired by singer-songwriter Adam Duritz, their music is melodic grunge, their lyrics full of irony and angst. In a song about a disturbed girlfriend, there is a verse that ends with the lines "Around here we talk just like lions।

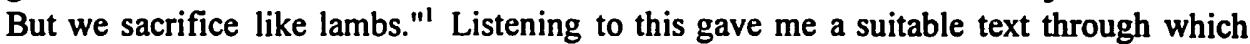
to set the thematic structure of my talk and to establish an appropriate postmodern posture. To be blunt, this paper is about how lawyers can talk the talk and walk the walk, but, when they are put to the test, their talk is often empty and their walk is usually all show. Instead of the lion it roars itself to be, the legal profession as a whole is a sorry flock of establishment sheep.

In a jurisprudential manner of speaking, I want to roam with the lions and run the theoretical risk of ending up in the belly of the beast, in order to avoid the practical fate of simply lying down with the sheep and falling politically asleep. In taking this defiant stance, my talk will draw on and continue a large and ambitious project that I have been engaged in, although not always by design, for some years: trying to understand and transform through legal theory what we do in our routine practices as lawyers, law professors and law students. In a very real sense, this discussion is a companion piece to Wes Pue's wonderful historical essay on the legal profession's myth-making. ${ }^{2}$ By

Associate Dean and Professor, Osgoode Hall Law School, York University, Toronto. This essay is a lightly edited version of a talk that I gave at the Calgary Conference. Many thanks to Adam Bernstein, Richard Devlin, Pam Marshall, Wendy Rambo and Jim Smith for their assistance and encouragement.

$1 \quad$ "Around Here" on Counting Crows, August and Everything After (1994).

2 W.W. Pue, "In Pursuit of Better Myth: Lawyers' Histories and Histories of Lawyers" (1995) 33 Alta. L. Rev. 730. 
drawing on a more theoretical set of materials, I hope to elucidate critically the kind of image that we have of ourselves as lawyers and how important that image is in informing what we do, how we justify what we do not do, and what we might become. It as much through the attachment to these blurry and impoverished visions as anything else that lawyers continue to follow the flocking sheep rather than lead as prideful lions.

Law and lawyering seems full of oxymorons. In the popular imagination, the most prominent of these is the notion of "legal ethics." For many, it is a contradiction in terms to talk about lawyering and ethical standards of behaviour in the same breath: lawyers are on a par with pariahs, not paragons. Indeed, some go so far as to suggest that to be a lawyer is to vacate the ordinary domain of ethical judgement and to inhabit a perverse world of normative disingenuity. In spite of (or perhaps because of) this common understanding, it is imperative to take on the task of re-thinking the ethics of lawyering. As the legal profession's status grows in terms of power and influence in public and private life, ${ }^{3}$ so too does the need to construct a re-vision of ethical lawyering that is consonant with its contemporary socio-economic organization and political responsibilities in a society that still, at least nominally, pays lip-service to the ideals of democratic governance and accountability. This challenge is particularly acute in the provision of available and appropriate legal representation to the least advantaged and most disenfranchised in society. Is there a sound and viable vision of what it is to engage in ethical lawyering for poor people? Is it really possible to remain a lawyer and be truly radical? Is the idea of ethical and radical lawyering merely oxymoronic in its expression or actually moronic in its aspiration?

By way of suggesting an intellectual framework within which to comprehend and address these pressing conundrums, I want to introduce the insights and injunctions of a postmodern way of proceeding. Again, for many, this will be heaving one more oxymoron into the already overcrowded space for thinking about legal practice. Insofar as it has any common currency and popular understanding, postmodernism is seen to be the very antithesis of a way of proceeding anywhere at all - more an indulgent wringing of anguished hands than a useful guide for practical action. As such, it might be thought to be the last thing that lawyers or their critics need to extricate the profession from its practical predicament of institutional (il)legitimacy. Nonetheless, I believe that a postmodern re-visioning of lawyering represents the best hope for the ethical renascence and political empowerment of legal practice in a contemporary democratic culture: it is the most effective and viable theoretical resource in a radical project of transformative politics. Concerns about the indefinite intimations of a postmodern strategy are understandable, but misplaced: there is no necessary contradiction between theoretical loyalty to a postmodern perspective and the practical implementation of a radical political agenda. ${ }^{4}$ While it does not provide the ground for

3 See H. Arthurs, R. Weisman \& F. Zemans, "Canadian Lawyers: A Peculiar Professionalism" in R. Abel \& P. Lewis, eds., Lanyers in Society: The Common Law World (Berkeley, University of California Press, 1988).

$4 \quad$ Contra A. Hunt, "The Big Fear: Law Confronts Postmodernism" (1990) 35 McGill L.J. 507; and G. Binder, "What's Left" (1991) 69 Texas L. Rev. 1985. 
progressive politics, postmodernism does constitute a complementary strategy. The progressive postmodernist and radical lawyer is not the oxymoronic character that the left rejects for its perceived conservatism and that the right fears for its assumed nihilism.

Rather than begin with an elaborate and abstract account of postmodern thinking, I will introduce postmodern premises and lines of argument in a suitably postmodern fashion - within the context of the implicit jurisprudential assumptions about law that underlie those regnant models of lawyering that themselves inform and inspire the daily routines and regularized decision-making of professional practitioners. Accordingly, the second section sketches and criticizes the traditional image and defence of the ethical lawyer. The third part looks at critical efforts to ameliorate the deficiencies of that traditional model. Although useful, such efforts remain very beholden to the mainstream assumptions and parameters of conventional lawyering. The fourth section responds to those progressive detractors who maintain that the image of an ethical lawyer or a radical lawyer is unavoidably perverse; lawyers are always part of the problem, never a component in the solution. While the fifth section introduces a postmodern way of thinking, the sixth part sketches a reconstructed vision of postmodern lawyering. The seventh section explores its implications for resolving persistent problems in the ethical practice of radical lawyering. ${ }^{5}$ This short article amounts to a preliminary meditation on what it might mean to act radically and ethically in a world in which notions of what counts as radical or ethical are always contested and contestable, and, particularly, what it might mean to do so as a lawyer.

\section{THE TRADITIONAL IMAGE OF THE ETHICAL LAWYER}

The traditional image of the ethical lawyer has remained largely static and unchanged for many decades. Although it has received considerable maintenance work by way of renovation and redecoration, the basic structure and foundations remain much the same. Caricatured as "hired guns," the more serious core of the traditional image is that of lawyers as hired hands. Little needs to be said of this image, for it remains the operating model through which lawyers are trained, under which most lawyers function and which is formally sanctioned by the provincial law societies. However, despite a lengthy and impressive historical pedigree, this model is very much a modernist one in the sense that it is based on a confidence in certain foundational assumptions, processes and values about law, society and ways of thinking about them.

The traditional image of lawyering is centred on the idea that lawyers are supertechnocrats; they possess a special set of talents and techniques which they deploy for the advantage of those people who hire them. They regard themselves as being neutral

This essay owes a very great deal to the insightful and important work of Anthony Alfieri. In a series of articles, he has offered both a powerful critique of traditional lawyering and a constructive alternative for transformative lawyering. I borrow unashamedly and extensively from his exposition of a theoretics of legal practice that promotes a vision of poverty law advocacy as a form of and forum for community education, local organization and political mobilization. See A. Alfieri, "Impoverished Practices" (1993) 81 Geo. L.J. 2567; and A. Alfieri, "Reconstructive Poverty Law Practice: Learning Lessons of Client Narrative" (1991) 100 Yale L.J. 2107. 
on the substance and form of the law; their task is very much to apply the law, a little to criticize it, but most certainly not to make it. The lawyer-as-hired-hand's commitment is to the legal system which, even when they are working around and within it, must be accepted as a given. If lawyers have a larger social calling, it is "to achieve the moral integration of [their] clients into the social order." ${ }^{.6}$ Almost indifferent to who their clients are, lawyers think of themselves as more chosen than choosing. The relationship between lawyer and client is built upon trust and respect: clients are to trust lawyers to act in the clients' best interests and, in return, lawyers will respect the clients' autonomy. It is not for lawyers to impinge upon that autonomy, but to act on behalf of the client to realize their interests and inspirations. Indeed, clients tend to be fungible. While it is recognized that richer and poorer clients will have different problems because of their wealth and that the appropriate strategies to be followed will be tailored to the particular client's needs and demands, they are entitled to equal access to the legal process. The lawyer-as-hired-hand treats all clients exactly the same, in the sense that they are each citizens who have had their rights infringed and want relief or vindication. Advocacy and action tends, therefore, to be standardized and made routine. Insofar as lawyers and clients are from different cultures and classes, lawyers are expected to bridge the gap by personal empathy and professional solidarity.

The fact that this traditional image still has great currency in the legal profession has much to do with the equally traditional theory of law from which it draws its shape and justification. For better or worse, the hallmark of good lawyers is considered to be their cultivation of rule-craft: the ability and possibility of identifying the extant rules of the legal system and applying them to particular situations. The central article of faith of this ultra-Hartian positivism is that rules are the basic currency of legal transactions and that their application can be performed in a professional and objective way. If not quite "the brooding omnipresence in the sky," law is an imposing and imposed structure that has considerable stability, that is operationally determinate in the guidance that it extends to the trained lawyer, and that is institutionally distinct from the more openminded disputations around ideological politics. As such, the image of the lawyer-ashired-hand embraces the idea that the law has a life of its own and is not influenced by the lawyers or legal officials who engage in the system. In this sense, any legal practice that craves and expects professional recognition must be seen to take law seriously and serve clients' interests through the extant rules, procedures and venues of law: overt politicization is severely frowned upon. It is a proud, unapologetic and loyal defence of The Rule of Law.

As attractive and as comforting as this image of lawyer-as-hired-hand may be to legal practitioners, its problems are manifest and manifold. It fails theoretically, empirically and ideologically: it is based upon a formalistic theory of law that is largely discredited and defunct as a serious attempt to understand law and its operation; it describes a version of legal practice that no longer has any empirical validity or historical accuracy, if it ever did; and it defends both its informing theory and 
governing practice of lawyering as apolitical in a way that merely serves to underline its very definite ideological commitments.

While mainstream jurisprudence continues to recognize an important role for rules in a modern legal system, almost all jurists of any credibility or respectability accept that the law is not as objective, stable or determinate as the image of lawyer-as-hiredhand maintains. It is not that they have abandoned a commitment to The Rule of Law and hold law to be irredeemably indeterminate, but that they hold that "law ... is deeply and thoroughly political ... [b]ut not a matter of personal or partisan politics." ${ }^{8}$ The coherence and intelligibility of law and lawyering are inextricably implicated in the contingent world of political values and ethical stances. The law never simply is and lawyering is never completely the passive and technical involvement in that is. Choice, and responsibility for those choices, are part and parcel of lawyering. Moreover, there is a certain disingenuity to lawyers' claims about the given nature of law. Once out of their apologist stance, it is hard to find a lawyer who actually proceeds on the basis that the law is fixed, certain and determinate. Sophisticated (and unsophisticated) lawyers recognize that the chance of success of most cases is attributable to more than the capacity of the opposing lawyer or presiding judge to get the law wrong: it is as much about the arguments made and the surrounding circumstances as anything else. If anybody doubted that, one only has to think what has happened under the Charter ${ }^{9}$ and the trajectory of resulting constitutional doctrine. ${ }^{10}$

In light of the empowered role and elevated status of lawyers in society, the lawyeras-hired-hand image is a very humble representation of what lawyers do and what people experience in their dealings with lawyers. For instance, it is fairly obvious that lawyers pick their clients indirectly through the fees that they charge. It is not that lawyers openly pick between competing clients but that only certain kinds of clients come into certain kinds of law offices: Imasco is not shopping around at the local mall for an affordable or available lawyer. There is nothing necessarily wrong with charging substantial fees for services, but the reality of high and variable legal fees confounds the claims of the lawyer-as-hired-hand image in this regard. Again, it is an unreal assumption to imagine that most clients, powerful and powerless, come to lawyers with anything but the most rudimentary notion of what they want and what is in their best interests. Indeed, it is often for the very reason of clarifying what those interests and values might be that brings some clients to lawyers in the first place.

A particular fallacy contained within the image of the lawyer-as-hired-hand is the belief that legal practice is much the same for those who serve disenfranchised people and those who work for more privileged clients; it is simply a matter of following different existing rules. Not only is access to legal services obviously disparate, the needs of the poor require a very different kind of lawyering. Treating all clients the 
same will do little to alleviate the situation of poorer people. Unlike more privileged people, their problems are continuing and systemic rather than sporadic and particular; legal problems do not arise in the otherwise smooth course of their life, but constitute and define much of that life. Whereas advantaged clients want their lawyers to use the system to remedy a discrete conflict, disenfranchised clients want their lawyers to change the system so that they can escape life's continual round of legal difficulties and bureaucratic hassles. "Apolitical engagement in social struggles through law is a luxury that poverty lawyers and their clients cannot afford.

Finally, the insistence that lawyering is a neutral exercise that does not implicate lawyers in any political process or demand a commitment to any particular ideology is as weak as it is wilful. Such an image is a profoundly conservative and crude understanding of what it is to engage in the business of courts, legislatures and the like: it accepts and works within the bounds of the status quo. Lawyers tend to confuse legal justice with social fairness. Indeed, the power and prestige of lawyers flows from their professional allegiance to the state's official laws and existing institutions; lawyers are the enlisted custodians of the status quo. By pretending otherwise and renouncing responsibility for the system that their actions hold in place, lawyers are able to maintain their so-called independence and political authority. As well as being a very misleading account of lawyering, the image of lawyer-as-hired-hand is an impoverished vision of the part that lawyers can and do play in the establishment of a substantively just society.

\section{IMPROVING ON THE TRADITIONAL MODEL}

Of course, dissatisfaction with the dubious assumptions and limited aspirations of the traditional image has led some lawyers to develop an alternative vision of lawyering, inspired by the Realist critique of law. It seeks to provide a better theoretical framework within which the practice of law can attempt to redeem the ideal of lawyering as a noble profession that places the needs of popular justice above the demands of institutional allegiance. While there is much nostalgic thinking behind this ambition, the belief that lawyers do more than simply seek enforcement of the law, and might occasionally turn the law to just ends, is a worthwhile and obvious improvement on the traditional image of the lawyer-as-hired-hand.

The controlling idea behind this image of the lawyer-as-civic-campaigner is the acceptance that law is not nearly so determinate, objective and stable as formalists maintain. ${ }^{12}$ Litigation and adjudication are much more value-laden and result-oriented than traditionalists suppose. Consequently, lawyers must take an appropriate share of the responsibility for those values and results. As players in the system, lawyers must be prepared not only to take credit for the good, but also to take blame for the bad. At the very least, they must engage in the struggle to make the legal process the best that it can be for the benefit of those who live under its directives, particularly the disadvantaged and the disenfranchised. As much as lawyers are officers of the law, they 
are also agents of the people; they ought not to uphold the law for its own sake, but must commit themselves to achieving justice through law. Lawyers should represent only those clients and causes that contribute to the furtherance of the common good. In this sense, lawyers are entitled and expected to straddle the roles of private partisan and public regulator. This does not mean that they should do (or not do) entirely as they please: lawyers must still obey "a general command to uphold the public purposes of legal rules"13 at the same time that they constantly challenge or uphold those rules to the extent of their consonance with the highest substantive ideals of a truly democratic polity.

Accordingly, rather than view lawyers as stoic mediators between "the determinate, articulated interests of a client and the determinate, articulated constraints of a legal or social system,"14 this realist-inspired critique considers it better to view them as creative constitutors who work the indeterminate relation between lawyers and clients to progressive effect. In doing this, lawyers are entitled to retain their own sense of autonomy in their relations with clients and to exercise their own ethical judgment as to the best course to follow. While not acting regardless of clients' wishes, clients represent an opportunity for lawyers to fulfil their own agenda of civic struggle and so lawyers ought only to take clients and adopt strategies compatible with that agenda. In a manner of speaking, lawyers and clients must be at one and form a team, with lawyers prepared to treat the case as if it were their own.

While the basis for this image of the lawyer-as-civic-campaigner is to move beyond the restricting confines of the lawyer-as-hired-hand and its formalistic underpinnings, it is a rather muted and only partial improvement. Although this realist image of lawyering recognizes that there is considerable indeterminacy throughout the legal process and that political involvement is virtually unavoidable, it does so in what is ultimately a weak and moderate way. Fearing that anything stronger and more uncompromising might result in "argumentative nihilism," 15 proponents hedge on the ramifications of accepting the incorrigible indeterminacy of law. They remain committed to a fairly traditional law-centred approach to social change and political struggle, in which it is generally thought important to respect the law's procedures and "to forego actions that would reduce its efficacy." 16 Accordingly, for the lawyer-ascivic-campaigner, uncertainty and choice are marginal and manageable features of the legal craft rather than debilitating threats to the very core of continued practice: law is as much part of the solution as it is part of the problem. There is a sufficient degree of operational efficacy to satisfy the need for professional self-respect and to refute criticisms of ideological illegitimacy. Despite intellectual protestations and critical tone, the lawyer-as-civic-campaigner is still a member of the "Rule of Law" family. 
In their zeal to escape the false modesty and political indifference of the lawyer-ashired-hand's image, the defenders of the lawyer-as-civic-campaigner's image seem to have jumped out of the frying pan into the fire. Eager to take more responsibility for what lawyers do, they have allowed the interests of lawyers to again eclipse the needs of clients. Both the lawyer-as-hired-hand and the lawyer-as-civic-campaigner fail to connect properly with clients. Whereas the former claims to accept clients' values and agenda at face value, the latter submerges them under the lawyer's own values and agenda. Although defended in the name of the common good and democratic empowerment, the image of the lawyer-as-civic-campaigner makes clients captive to one more elite cult of expertise, which claims to know what is best for clients and everyone else. On the road to civic redemption, lawyers are the drivers; clients can only take a back seat and enjoy the ride. Lawyers decide who is deserving of access to legal services and representation, what is best for those people taken on, and how their interests should be furthered. This is aristocratic rule masquerading as popular justice.

No matter how enlightened or well-intentioned, this way of proceeding is paternalistic and patronizing: it glorifies lawyers individually at the expense of people generally. Rather than demystifying the allure of the legal system and reducing the power of lawyers, the image of lawyer-as-civic-campaigner actually increases law's prestige and lawyers' importance. For instance, the integrationist impetus of much American civil rights litigation of the $60 \mathrm{~s}$ and $70 \mathrm{~s}$ failed to respect the political demands of blacks for local schools over which black communities could exercise some control: the lawyers' visions overwhelmed and took precedence over the clients'. ${ }^{17}$ While lawyers may well have a role to play in the struggle for greater social justice, it is a much more humble and much less presumptuous one. Instead of succumbing to the urge to become authority figures, thus turning the lawyer-client relationship into an occasion for moral education, lawyers might attempt to nurture a political dialogue in which both lawyers and clients can share, learn and change; one from which some mutually viable way of proceeding - albeit not anything as pretentious or preposterous as the right thing to do - might emerge. In this vision of lawyering, lawyers would not be merely mouthpieces for their clients' views, nor would they use their clients as soapboxes for their own preferred causes. The ambition would be to establish the lawyer-client relationship as a conversational microcosm of democratic culture involving two citizens, both able and entitled to contribute fully. This is the key to rethinking the shift from traditional images of lawyering to a more postmodern approach to the role and possibilities of lawyers.

\section{THE LAWYER AS A LOST CAUSE}

Before sketching in the shape and substance of postmodern lawyering, there is one other view of lawyering that has to be considered. I hesitate to call this an image of lawyering, because it actually maintains that legal practice is almost always a lost cause by the measure of all truly progressive politics: it is not possible to be a lawyer and to be politically progressive. Radical lawyering is an oxymoronic pursuit of the first order. 
This unmitigated critique of the legal profession takes its lead, in a manner of speaking, from Shakespeare's Dick: "The first thing we do, let's kill all the lawyers."18 The law is basically a corrupt enterprise, in cahoots with all kinds of public and private interests to preserve the status quo. Lawyers are major sub-contractors in the capitalist enterprise of maintaining class relations; their professional ideology and action help to constitute and hold in place social relations and official institutions. The real bargain between lawyers and clients is not one of trust and autonomy, but one in which many lawyers are willing (and eager) to sell themselves and their consciences to the highest bidder. For such critics, the very reasons that gave rise to law and rights' original appeal have become the source of their contemporary failure as a program for progressive change: universalistic pretensions, unyielding individualism, social insensitivity and pervasive blindness to history.

Involvement with the legal system is co-optive because any resort to law or the courts for political relief reinforces the legitimacy of the very system which sustains the oppression in people's lives. Any victories are quickly neutralized by bureaucratic inertia, political intransigence and judicial complacency. Hard-won litigation victories have had only negligible effects on providing better health care, education, housing, employment, and other substantive changes in people's material lives. ${ }^{19}$ As Canada's relatively brief experience with the Charter shows, even the most progressively-inspired successful litigation is more likely than not to result in weapons for future struggles being handed to better-resourced enemies of radical change. The history of social struggle suggests strongly that the prospect of significant social change through litigation is "a teasing illusion like a munificent bequest in a pauper's will."20 Accordingly, whether as a categoric system of political practice or as a contingent strategy of radical intervention, law and lawyering can never be productive of real or lasting social and economic improvement.

Many people will identify much of my work with this kind of generalizing and dismissive critique of law and lawyers. Undoubtedly, I have written pieces that contribute to such a genre of scholarship. ${ }^{21}$ Nevertheless, I have begun to reconsider some aspects of that stance in recent years. This is not to say that I have rejected many of the main contentions of such a critique. I still maintain that the routine resort to courts is profoundly mistaken: it dissipates large amounts of scarce radical energy, it fails to involve citizens as democratic participants in the process of change, and it has a very limited and limiting effect on social change. Yet this line of argument has a tendency to become too polarized, too blunt and too unrealistic in both its critical

18 W. Shakespeare, Henry VI, Part 2, in A. Harbage, ed., William Shakespeare: The Complete Works (New York: Viking Penguin, 1977), Act IV, sc. ii, I. 70.

19 See D. Bell, And We Are Not Saved: The Elusive Quest for Racial Justice (New York: Basic Books, 1987) at 25-74, 140-61 and 215-35; and J.C. Boger, "Race and The American City: The Kerner Commission in Retrospect - An Introduction" (1993) 71 N.C.L. Rev. 1289. claims, see A. Hutchinson, "Les Miserables Redux: Law and The Poor" (1993) 2 S. Cal. Interdisc. L.J. 301 at 326-31.

21 See e.g. A. Hutchinson, Dwelling on the Threshold: Critical Essays on Modern Legal Thought (Toronto: Carswell, 1988). 
analysis and political recommendations. In the same way that it is no longer possible to invoke "material interests" or "class analysis" as the decisive ploy in political argument, forswearing engagement in law or lawyering entirely is not a viable or responsible tactic. ${ }^{22}$ Like the abstract instincts and intimations of the traditional image of lawyering, the reductionist politics of class struggle fail to sufficiently respect differences of race, gender and sexuality in its totalizing march to social justice. Such a radical campaign can too easily fall victim to the same kind of universalistic judgment that afflicts the lawyer-as-hired-hand's all-or-nothing embrace of litigation as a political way of life.

On the legal front, the debilitating problem with this critique is that, ironically, it is based on a very formalistic understanding of law and society - stable, determinate and objective - that shares much with the traditional image of the lawyer-as-hired-hand and its jurisprudential footings. The major difference, of course, is that radical critics reject the substantive values that such a legal process represents and enforces; what traditionalists treat as just, these critics see as oppressive. The political danger of the old-style left is that, as well as overestimating the "thereness" of law, they underestimate the transformative impact that individual agents and legal interventions can have. ${ }^{23}$ Law is much more indeterminate and, therefore, manipulable than either traditionalists or their critics appreciate. While it is crucial not to exaggerate the contributions of the court, it is equally important not to deny entirely the possibility that legal forums can contribute to transformative struggle. Lawyers are not always and not only "the goon squad of the ruling class." 24

Consequently, although I accept that the commitment to a Rule of Law mentality has actually betrayed the cause of democratic governance and egalitarian justice, ${ }^{25}$ I concede that it is not possible or desirable to completely ignore lawyers and litigation in a society so thoroughly pervaded by law and lawyers. While both the wholesale adoption and rejection of litigation as a schematic process for substantial social renovation are fundamental errors, the critical challenge is to move beyond such political stereotypes and their one-dimensional narratives of transformative action. The choice is not so stark or binary in the struggle for progressive change and social justice. Mindful that there is no "outside" from which to work, there may be occasional strategic advantage in making "inside" resort to the courts in the struggle to advance the project of progressive justice. It involves the precarious but unavoidable task of trying to tread a thin line between engaging with the system and being co-opted by that system. The only other choices are to withdraw entirely and wail in the wilderness or

See M. Mandel, The Charter of Rights and the Legalization of Politics in Canada, 2d ed. (Toronto: Wall \& Thompson, 1994) and J. Fudge \& H.J. Glasbeek, "The Politics of Rights: A Politics With Little Class" (1992) 1 Soc. and Legal St. 45.

See R. Nelson \& D.M. Trubek, "New Problems and New Paradigms in Studies of the Legal Profession" in R. Abel et al., eds., Lawyers' Ideals/Lawyers' Practices: Transformations in the American Legal Profession (Ithaca: Cornell University Press, 1992) 22. 
to go underground and foment bloody revolution. Neither of these seem attractive or tenable solutions in Canada today.

\section{A POSTMODERN WAY OF PROCEEDING}

So what do I offer in place of these three discredited versions of lawyering? Although I hesitate to use labels, I want to offer an idea of what a postmodern vision of lawyering might look like. Or, more accurately, I want to suggest what lawyers might think about themselves, the system in which they work and the moves that they would make if they had a postmodern way of thinking. In doing this, my aim is not simply to colonize the middle ground between the cultivated professional neutrality of the lawyer-as-hired-hand and the imposed political viewpoint of the lawyer-as-civiccampaigner. Instead, I want to get beyond this polarized and dichotomous way of proceeding. Nor do I want to take off on some flight of juristic fantasy and boldly go where no one would care to go in a misguided attempt to redeem the dubious ideal of "justice through law." I want to situate a vision of postmodern lawyering in the hereand-now. The ambition is not mild reform or wild revolution, but a vigorous practice of transformation and transgression. In the familiar imagery of Neurath's nautical metaphor, ${ }^{26}$ the legal profession is already well launched on the historical sea and unable or unwilling to return to the dry-dock for a complete overhaul. If change is to be effective, it must be made one plank at a time and while the ship is still at sea.

The most crucial injunction of postmodernism is, as the French theorist Lyotard put it, that there should be an "incredulity towards meta-narratives." ${ }^{27}$ Contary to the universalistic pretensions of both traditionalists and radicals, there is no one simple and straightforward account that can be given of the legal process which is cogent or valid as an accurate description of what goes on, or is a reliable prescription of how to change it. The only constants about law, society and their interaction are their messiness and contingency. They are in a constant state of flux and any theoretical attempt to favour one explanation of the role of the lawyer is doomed to failure. The theory and practice of law are indeterminately political and politically indeterminate. There is no non-political stance to practicing or theorizing about law; all claims to neutrality are premised on an often undisclosed and usually unnoticed set of controversial normative commitments. Postmodern lawyers will not resist or hedge on this enduring indeterminacy and inescapable politics, but learn to accept and utilize it for progressive ends.

At different times and in different ways, the lawyer must be prepared to adopt a variety of strategies and interventions. Most importantly, lawyers and scholars committed to progressive action in a postmodern world must resist the temptation to seek theoretical closure and practical dogma. They must decline the familiar litany of easy answers in favour of a more challenging slate of better and different questions:

See O. Neurath, "Protocol Sentences" in A.J. Ayer, ed., Logical Positivism (Glencoe: Free Press, 1959).

27 J.-F. Lyotard, The Postmodern Condition: A Report on Knowledge, trans. G. Bennington \& B. Massumi (Minneapolis: University of Minnesota Press, 1984). 
"we have learned the answers, all the answers: it is the question that we do not know. ${ }^{128}$ Closure is always contrived, frequently arbitrary and usually conducive to established power relations. Obsessed with elucidating correct and final answers, progressive scholars often forget that the agenda of questions to be answered is constantly changing. Justice is not a matter of revelation, and progress is not a slow march to a promised land always around the next historical bend. In a postmodern world, justice is less obvious and living is more immediate and engaged. Importantly, a postmodern critique is neither apocalyptic nor visionary. It is a constant interrogation and calling into question of all those ideas and practices most familiar to us. It is not possible to make a clean break from inherited tradition and "one risks ceaselessly confirming ... that which one allegedly deconstructs. ${ }^{.29}$ However, while there are always and already parameters to action, those boundaries must also be part of the struggle: contact and situation is not the same as complicity and satiation. The challenge is to condemn unfailingly the injustices of the present system, but at the same time, to affirm constantly the possibilities for transformation; to be a deconstructive pessimist and a reconstructive optimist.

Liberals and radicals alike are correct in thinking that my constructive proposals cannot guarantee a politics that will be uniformly progressive or whose practice will be consistently effective. But, to think otherwise is to continue in the belief that the establishment of foundational truths is possible and can ground a radical political praxis. The perceived need that people have for such solid ground under their metaphysical feet is an effect of traditional theory's mistaken insistence that, once fixed, Truth, History or Right will guide and insulate action from error. Disabused of such traditional metaphysical yearnings, people will begin to understand that politics is inside, not outside, of History's suzerainty. A program of progressive politics must constantly be negotiated and renegotiated. What is progressive can never be determined in advance or in the abstract; such assessment can only be made with attention to the local conditions and prevailing exigencies of the situation. All the critic can do is open spaces for action and increase opportunities for transformation, but he or she cannot fill those spaces. Whether these openings become holes to fall down or climb out of is left to those minded to act. Citizenship in a postmodern polity is not a received status, but is a continuing responsibility to make the best of the situation for oneself and for others.

All that a postmodern mentality can do is show that power is never apart from reason. Logic and ambiguity, authority and arbitrariness, and universality and contingency are implicated in each other. By leaving the risks and responsibility of reconstruction with real people in real situations, what is good politics or best for the community will always remain contestable. There is no guarantee against tyranny; nothing can deliver us from that. While there must be talk of a dawn of egalitarianism, 
there are many who still live in the dusk and darkness of oppression..$^{30}$ No theoretical standpoint can alone ensure that the long night's journey into light can be accomplished without struggle, mistakes and further pain. The challenge and trick for radical critics is to nurture and develop those talents and sensibilities that will better attune them to the nuances and vulnerabilities of structural settings and local contexts. Relieved of the anxiety to craft solutions somehow apt for all times and places, they will be able to concentrate on the pressing problems of contemporary Canadian society, and experiment with interventions that can best address the prevailing institutional structures of power.

Nevertheless, a postmodern temper is not silent on what might generally amount to a progressive politics. Postmodernism implies a participatory democracy that is egalitarian and pluralist, in order to inspire the robust kind of institutional arrangements that will permit the articulation and antagonism of different modes of life. Of course, the question of what best serves and advances the idea of democratic practice is constantly open to interrogation. In a democracy, "bad" forces might carry the day, but only the day: tomorrow is always another day and another occasion to engage and transform democracy and its contingent experience. Such a commitment demands the mobilization of popular energies rather than the application of pseudo-expert knowledge. Poor lawyering must, therefore, be itself a focus and forum for democratic engagement where politics is open and judgment is contingent. As occasion for resistance through empowerment, lawyering must remain piecemeal, situated, responsible and humble. Ambivalence and doubt are not only inescapable features of postmodern lawyering, but desirable aspects of it. Without doubt and ambivalence, the temptation to hubris is all too irresistible.

\section{A RECONSTRUCTED VISION OF POSTMODERN LAWYERING}

The first imperative is that, if legal practice is to be transformative, legal practice itself must first be transformed. At present, lawyering does not march to the beat of the client's drum, but to the organizational imperatives of the legal profession. This is effected in myriad ways, and exploring possible means of transformation - loss of monopoly and self-regulation, socialized legal services, etc. - is well beyond the scope of this paper. Nevertheless, there are three primary obstacles to the realization of a truly radical legal practice: lawyers are trained to see law and its institutions as just and necessary structures; there is a professional discipline of political neutrality; and the social organization of the profession and its continuing lack of real diversity in membership marginalize any alternative or challenging modes of lawyering. ${ }^{31}$ This will require changes not only in the legal profession, but also in the way legal education is carried out; law schools and the professorate must accept their share of the blame for the profession's continuing state of affairs. 
As part of this overhaul, a very important initiative will be to institutionalize and accelerate the diversification of the legal profession. Instead of paying lip service to the idea, there must be aggressive and sustained efforts to open up the legal profession to the many different groups that presently face significant barriers to entry. Indeed, some of those changes have already taken place and it is for the profession's ruling bodies and establishment to recognize and accommodate that fact. It is already impossible to proceed on the basis that there is such an entity as the lawyer, a fungible professional model that can stand in for and represent the profession. There are many different kinds of lawyers and ways of lawyering: small firms, large firms, sole practitioners, urban practices, rural practices, generalist firms, specialist firms, female firms, ethnic firms, etc. It flouts social reality to pretend that legal regulation or instruction can be based upon anything but pluralist and multiple visions of legal practice.

Of course, in spite of the diversity in forms of business organization and delivery of legal services, the legal profession is still a bastion of privilege and elitism that is largely populated and dominated by white, middle-aged men of old European stock. In the same way that the cultural and ethnic diversity of Canada has changed, so must the legal profession reorganize itself to reflect this postmodern fact of social living. It is not, as John Major puts it, that there are "special" groups and societies whose interests must be recognized and whose members must be absorbed into the legal profession. ${ }^{32}$ The only "special" group in the Canadian legal profession is the one that has controlled its affairs and self-image for decades. Effective transformation will only occur when that group is willing or obliged to relinquish its hold on power. The only real changes in the system will come when the composition, demographics and, therefore, lifeexperience of lawyers change and their different views of what it is to be a lawyer are not just tolerated, but displace or transform the regnant images nurtured by the dominant group in society and falsely heralded as neutral in operation and design.

On the personal front, the most radical move would be to urge lawyers to take individual responsibility for what they say and do in their professional capacities. By rejecting the hackneyed and unsustainable notion of an entirely differentiated role, lawyers might begin to gain the respect of the public and themselves. In the same way that good oratory is a good person speaking well, ${ }^{33}$ good lawyering is a good person acting well. As trivial and trite as this may seem, it is the best advice that can be given to the fledgling lawyer and the most compelling injunction to the jaded lawyer. It offers no magical guide as to what to do in any specific or conflicted situation, because there is none to be given. It is for each person to arrive at an informed and conscientious decision in accordance with their own political and moral lights. The objective is not to chastize lawyers simply because they are corporate lawyers or represent rapists and bigots: it is to encourage each lawyer to take responsibility for the clients they take, the causes they fight for and the tactics they use. In doing so, however, the postmodern lawyer will ensure that those moral and political lights are always brought into play and are themselves open to debate and re-consideration. In the postmodern play-book, the 
goal is not an enforced and impersonal orthodoxy, but a respectful and responsible heterodoxy.

The directive to lawyers to take responsibility for what they do (and omit to do) ought not to be viewed as an excuse for ignoring the needs of clients, or for taking control of a legal case in the same way as realist critics openly defend and traditionalists covertly effect. The recommendation is to be neither the clients' unquestioning servant nor their know-all master. Instead, lawyers and clients are to work toward a non-hierarchical relationship that is premised on the fact that they both have something to contribute - the lawyer's insider knowledge and the client's outsider perspective - to the joint enterprise in which they are equally, if differently, engaged. An important distinction here is between lawyers' personal sets of substantive values and the more general constraints of their moral convictions. Postmodern lawyers will not foist their own values on the client, but neither will they work with clients in ways that offend their moral convictions. The lawyer-client relationship should be mutually respectful and engaged.

Also, in assuming responsibility, it is important that lawyers look beyond their dealings with their own clients. Part of any mature understanding of what amounts to responsible behaviour will include in its moral almanac the belief that one should do as little harm as possible. ${ }^{34}$ Although it will make life much more complicated, it is incumbent on postmodern lawyers to weigh the effects of their actions on other people and the harm that will ensue. This is to say little more than that society has a stake in the legal profession's actions and this should be accepted by lawyers. Again, this is a matter in which there is no magic formula: every lawyer will have very different views about the weight to be attached to different considerations and how they are to be weighed against the obligation to their clients and themselves. Contrary to popular misconceptions, a portrait of postmodern lawyering is not painted exclusively in the familiar shades of moral grey: it is a living video filmed in bold and bright colours, whose edges are constantly blurred and whose contrast is continually shifting.

\section{IMPLICATIONS FOR THE ETHICAL PRACTICE OF LAW}

The claim that law is eternally and inescapably political has profound implications for all lawyers. As well as undermining the mainstream jurisprudential project and its images of lawyering, it obliges postmodern critics to take seriously the legal process as a formative constituent of social life and as an important arena for political struggle. This does not mean a lemming-like rush into the courts nor an unconditional embrace of the Rule of Law: these responses are more suited to the born-again jurisprudential zealot than the progressive sceptic. The belief that there will either be a complete absence of law or a positivistic form of democratic law in a transformed world are both dangerous fantasies. A transformative view of law demands more than a facile pouring of new wine into old institutional bottles of liberal formalism, or a mere change in the 
personnel of the state. It requires a critical understanding of the political nature of legal structures, their instrumental limitations and their resistance to accommodating change. In short, a constitutive theory of law, infused by a sense of historical indeterminacy and political contingency, can be conducive to the ambitions of progressive lawyering and can best guard against "the slide into reformism or cynicism." ${ }^{35}$

Accordingly, progressive scholars must look for better and different ways to empower disadvantaged groups. In effecting such a proposal, two actions must be taken. The first step is to raise the critical consciousness of lawyers by disabusing them of their ingrained habit of resorting to the courts as the transformative forum of choice. They must become more sensitive to the debilitating effect of extended involvement of courts in civic life. Litigation and adjudication are special social activities that do not so much cause or condition, but comprise and are constitutive of extant social conditions. As such, it is dangerously naive and overly romantic to contend that courtenforced rights can, will or should be the preferred medium for social activists. Litigation has a distinct tendency to present clients as victims in need of help, rather than as survivors claiming their rightful share of power. ${ }^{36}$ It is a self-serving conceit for lawyers to encourage the continued use of litigation as a constructive and viable route to social justice. The language of the law has very often been and continues to be the language of the poor's subjection and misery. Not only is it difficult, as a practical and instrumental matter, to challenge subordination within and through the very institutions that subordinate people, but there is also the political and ideological grip that judicial discourse places on its participants: "the legal forms we use set limits on what we can imagine as practical outcomes." ${ }^{37}$

Ultimately, any gain achieved through litigation will serve to lend popular credence to the legal system as a legitimate arena for successful transformative activism. To engender respect for any right gained and to ensure their effective enforcement, it will be necessary to instill a general reverence for the courts as a whole. In this, the radical critics are undoubtedly right. ${ }^{38}$ While such a strategy might allow small advances to be made, it will actually defer and inhibit the kind of profound changes necessary for truly progressive transformation; minor improvements are the obstacles, not the precursors to major innovation. Being abstract and potentially universalistic, rights-talk has no required political content and application: rights-talk is a site for struggle and occupation, not a completed project. Consequently, any right can be ambushed and held hostage by non-progressive lawyers, and turned to the advantage of their own (privileged) clientele. Indeed, this is exactly what has happened in Canada. In the first three years after the introduction of the Charter's equality provision (s. 15), there were approximately 600 judicial considerations of the section, of which forty-four decisions,

$35 \quad$ K.E. Klare, "Law-Making As Praxis" (1979) 40 Telos 135.

3. See K. Bumiller, The Civil Rights Society: The Social Construction of Victims (Baltimore: Johns Hopkins University Press, 1988).

37 Gordon, supra note 12 at 111.

38 See H.J. Glasbeek, "Some Strategies For an Unlikely Task: The Progressive Use of Law" (1989) 21 Ottawa L. Rev. 387 at 396. 
or 7 percent, involved sexual equality. ${ }^{39}$ Most alarmingly, only seven of these cases were initiated by or on behalf of women; the other thirty-seven decisions were based on claims by men. Moreover, while obvious and important gains have been made through Charter litigation, they have tended to expand notions of due process and natural justice; they have not strengthened the arm of the oppressed to challenge or dislodge the elite brokers of established power.

Secondly, imbued with an appropriate sense of critical consciousness, progressive lawyers should develop a self-conscious program of strategic scepticism. Mindful that the details and priorities of a progressive politics must be the continuing subject of healthy debate and respectful disagreement, such a program would be more the cultivation of a particular mind-set and the refinement of various tactical techniques than the establishment of a manifesto of litigable claims. The core idea is to act in a guerrilla-like way: within a broad set of progressive objectives, to seize the possibilities of any contingent moment, in order to achieve judicial decisions that heighten the status quo's contradictions and open up space for lasting political action. Of course, the fact is that many of the disadvantaged and disenfranchised are not accorded the privilege of choosing the institutional site or rhetorical conditions of their struggle for social transformation. Nevertheless, this is not as significant nor as debilitating as might first be thought. The first step to enlightenment is the recognition that there is no available "outside" from which to engage in transformative action: all struggle is already situated within the mechanisms that must be resisted and reworked. The struggle must commence from where we are, with the historical problems and possibilities of the present. The only available strategy is to develop legal tactics that politicize and disrupt the courts in the process of using them for litigation. ${ }^{40}$ The challenge is to engage in law and, at the same time, to delegitimate it by eschewing abstract notions of justice and rights in favour of concrete and individual, site-specific challenges.

As well as perpetuating the idea that justice comes from a judicial act of noblesse oblige rather than being a product forged at the anvil of social struggle, dependence on litigation struggles over rights will dissipate much valuable energy that could be better used elsewhere. Direct citizen involvement is always to be preferred to litigation. At the heart of any progressive campaign for social justice, there must be a firm commitment to the development of popular coalitions - so that the disenfranchised can become part of their own empowerment. Steps Back? (Ottawa: Canadian Advisory Council on the Status of Women, 1989). Instead of being necessarily about the equality concerns of the disadvantaged, the equality provision has been used to deal with issues such as drunk driving and the manufacture of pop cans. See Mandel, supra note 22. Nevertheless, Brodsky \& Day still believe that the problem has been primarily doctrinal. For a sceptical critique, see J. Fudge, "The Public/Private Distinction: The Possibilities and Limitations to The Use of Charter Litigation in Further Feminist Struggles" (1987) 25 Osgoode Hall L.J. 485; and B. Cossman, "Dancing In The Dark" (1990) 10 Windsor Y.B. Access Just. 223. "Building Power and Breaking Images: Critical Legal Theory and the Practice of Law" (1983) 11 N.Y.U. Rev. L. \& Soc. 369; and C. Smart, "Feminism and Law: Some Problems of Analysis and Strategy" (1989) Int. J. Soc. L. 109. 
If a true democracy is to be the goal, it must be effected by means that are themselves thoroughly democratic in nature. For instance, in responding to the plight of the homeless, those very people can be involved as paid consultants and workers in the planning and (re)building of affordable housing and public amenities so that, once such homes are created, they might be able to pay their way in their co-operative management and maintenance.

The shift from a less individual-centred and rights-based approach to a more groupbased and power-oriented program will facilitate this ambition. In this way, it might become possible to "recognize and accommodate the political importance of process over legal goals and build links with communities whose perspectives..." are not usually or easily represented in the jejune practices of litigation. ${ }^{41}$ Apart from abjuring the tendency toward litigation, the lawyer has an important role to play in such a program. While it will involve a re-orientation of what is traditionally understood to be the primary skills of lawyering, a revised legal practice will still call upon many of the peculiar talents of lawyers for sophisticated organization and sound planning. Even the model of the good corporate lawyer can be appropriated and given a community-based twist; lawyers could seek to do less fire-fighting and more pre-emptive planning. In facilitating the establishment of community institutions and infra-structure, lawyers can enhance a co-operative's capacity to make informed decisions about its own development and activities; they can nurture a democratic culture and organizational structure that meets the need and wishes of its members. ${ }^{42}$ In this way, the lawyer becomes a public contributor to, rather than a private adversary of, the civic community.

\section{CONCLUSION}

Although I have been very down on the profession, I still believe that if there is to be change, it must come as much through the legal profession as in spite of it. It is those relatively few committed and concerned members that will have to bear the leonine share of responsibility for pulling it out of its ovine situation. In order to do that, lawyers must be prepared to abandon the habits of a lifetime and speak "truth to power." Rather than rest snug in power's comfort and privileges, they must risk the anger and rejection of the establishment. The profession must serve citizens at large and not themselves. In doing this, lawyers will accept such an obligation as a matter of civic trust, not as an exceptional act of charity or, as John Major seemed to be suggesting, a good business move. ${ }^{43}$ The last thing that lawyers need to do is to resurrect a vision of lawyering that draws on the aristocratic language of noblesse The Pursuit of Equality (Toronto: Second Story Feminist Press, 1991) at 57. 1317; R.C. Slye, "Community Institution Building" (1991) 36 Vill. L. Rev. 1035; and J.S. Lehman \& R.E. Lento, "Law School Support For Community-Based Economic Development in LowIncome Urban Neighbourhoods" (1992) 42 Wash. U.J. Urb. 65.

43 See Major, supra note 32. When lawyers talk about doing pro bono work, it suggests either that they have become fans of $\mathrm{U} 2$ or that they spend most of their time doing pro mala work. 
oblige. It is no use roaring like the mythical lion, if all we end up doing is bleating like the proverbial sheep.

As much as a democratic society demands postmodern lawyers, a postmodern society needs postmodern lawyers. There is no hard truth out there to which lawyers can cling in the vain hope that it will relieve them of the professional and personal burden of taking responsibility for what they do. There are just different visions of what we can be as lawyers, and through which we can try to vindicate ourselves from our actions as citizens in a civic and postmodern world. As an incorrigible romantic (in a postmodern sense, of course), I ask you to take seriously Tennyson's Ulyssean incitement to moral redemption:

Come, my friends,

'Tis not too late to seek a newer world ...

Though much is taken, much abides; and though

We are not now that strength which in old days

Moved earth and heaven, that which we are, we are,

One equal temper of heroic hearts,

Made weak by time and fate, but strong in will

To strive, to seek, to find, and not to yield.

Or, as temporary citizens in the city of rodeos and stampedes, we might look forward and, as far as the transformation of the legal profession is concerned, look back on "Calgary and Everything After." Like that great postmodernist and film actor Robin Williams said (by way of Horace's Odes), Carpe Diem. 